\title{
XCL1 wt Allele
}

National Cancer Institute

\section{Source}

National Cancer Institute. XCL1 wt Allele. NCI Thesaurus. Code C50973.

Human XCL1 wild-type allele is located in the vicinity of $1 \mathrm{q} 23$ and is approximately $5 \mathrm{~kb}$ in length. This allele, which encodes lymphotactin protein, is involved in lymphocyte trafficking and inflammatory processes. 